\title{
Nutrient Removal Using Fermented Organic Acids Derived from the Primary Sludge in the Intermittent Aeration Activated Sludge Process
}

\author{
Seung-Yeon Weon ${ }^{1}$, Sang-Il Lee ${ }^{1}$, Chan-Won Lee ${ }^{2 \dagger}$ \\ ${ }^{1}$ Department of Environmental Engineering, Chungbuk National University, Cheongju 361-763, Korea \\ ${ }^{2}$ Department of Urban Environmental Engineering, Kyungnam University, Changwon 631-701, Korea
}

\begin{abstract}
The two-stage intermittent aeration activated sludge process (IAP) and dynamic-flow intermittent aeration activated sludge process (DFP) were investigated for the nutrient removal of domestic wastewater. Three sets of IAP and one set of DFP were operated. The fermented settled sludge taken from the primary settling tank was added to two IAP and one DFP as an external electron donor, with one IAP, in which an external carbon source was not added, as a control. All the systems were operated at a sludge retention time of 20 days and a hydraulic retention time of $12 \mathrm{hr}$. A Higher denitrification rate was observed with the fermented settled sludge for the denitrification compared to the process without the addition of the organic source. The result indicates that the fermented acid from the primary domestic sludge has been proved to be an excellent electron donor for denitrification and biological phosphorus removal with IAP and DFP in treating relatively low $\mathrm{C} / \mathrm{N}$ ratio(Carbon / Nitrogen ratio) wastewater. Phosphate accumulating organisms have a capability of competing with denitrifiers in the presence of volatile organic acids under anoxic conditions.
\end{abstract}

Keywords: Denitrification, Dynamic-flow intermittent aeration, Electron donor, Fermented acids, Phosphate accumulating organisms, Two-stage intermittent aeration

\section{Introduction}

The traditional and conventional activated sludge processes such as anaerobic/anoxic/oxic $\left(\mathrm{A}_{2} \mathrm{O}\right)$, Bardenpho, University of Cape Town (UCT), and Virginia Initiative Project (VIP) are operated at steady state under oxic, anoxic, and anaerobic conditions for nutrient removal. Meanwhile, the processes such as Biodenipho, Bio-denitro, and intermittent aeration system are operated at a dynamic state. Their operating systems are not fixed and alternate periodically depending on the characteristics of the wastewater treated $[1,2]$.

The intermittent aeration activated sludge process (IAP) and dynamic-flow intermittent aeration activated sludge process (DFP) are a modification of the regular activated sludge system, in which the major frame remains the same and the status of oxygen in the reactor is controlled by proper alternation of aeration time. Nitrogen and phosphorous removal in the intermittent aeration process was evaluated by Osada et al. [3] and Sasaki et al. [4]. One of the advantages includes nitrification and denitrification as well as biological oxidation of carbonaceous matter in the intermittent aerated stage. The nitrogen and phosphorus removal from wastewater is dependent on the ratio of biochemical oxygen demand (BOD) to nitrogen (N). The wastewater might not contain sufficient easily biodegradable organic matter to achieve the desired level of biological nutrient removal, especially biological phosphorus removal. Therefore, if the ratio of BOD to $\mathrm{N}$ is less than 4 , the external $\mathrm{C}$ source should be provided $[1,3,5]$. Most of the readily degradable wastewater organic matter is oxidized in the oxic reactor. Denitrifying bacteria are mostly heterotrophic, in which their carbon for cell biosynthesis is obtained from organic compounds. Many possible electron donors for heterotrophic denitrofication are domestic wastewater organics, acetate, methanol, ethanol, food and processing wastes. Although any biodegradable organics can serve as a carbon source, methanol is common because of its availability, ease of application, and ability to be applied without leaving a residual BOD in the process effluent [6]. Van Munch and Greenfield (1998) [7] have completed researches on prefermenter performance and modeling. Prefermentation for biological nutrient removal is defined as the production of volatile fatty acid (VFA) from domestic or industrial wastewater by subjecting the wastewater to anaerobic conditions for a period of time.

Lee et al. [8] reported that higher denitrification rates were obtained with fermented primary sludge than with either methanol (c) This is an Open Access article distributed under the terms of the Creative Commons Attribution Non-Commercial License (http://creativecommons. org/licenses/by-nc/3.0/) which permits unrestricted non-commercial use, distribution, and reproduction in any medium, provided the original work is properly cited.
Received July 15, 2010 Accepted November 25, 2011

${ }^{\dagger}$ Corresponding Author

E-mail: water@kyungnam.ac.kr

Tel: +82-55-2492247 Fax: +82-505-999-2131 
or acetate. The purpose of this study is to evaluate the potential ofVFA prefermented from the primary sludge of domestic wastewater as an external carbon source for nitrogen and phosphorous removal in the anoxic reactor of a two-stage intermittent aeration process and a dynamic-flow activated sludge process.

\section{Materials and Methods}

\subsection{Characteristics of Domestic Wastewater Used}

The wastewater used in this study was collected two times every week from a domestic wastewater treatment plant located in Cheongju. Chemical oxygen demand (COD) concentrations ranged from 105 to $540 \mathrm{mg} / \mathrm{L}$. The characteristics of domestic wastewater influent are shown in Table 1. The average concentrations of COD, TKN, and TP (Total Kieldahl Nitrogen, and Total Phosphorous)were 235, 32, and $5.4 \mathrm{mg} / \mathrm{L}$, respectively. After passing through GF/C filter paper (Whatman, Kent, UK), the concentration of SCOD (Soluble Chemical Oxygen Demand) was $95 \mathrm{mg} / \mathrm{L}$, which is equivalent to $40 \%$ of total COD. $26 \mathrm{mg} / \mathrm{L}$ of average ammonium nitrogen was measured in the influent and the ratio of total BOD to TKN was 1.46

\subsection{Two-Stage Intermittent Aeration Activated Sludge Process}

Fig. 1 shows a schematic diagram of the IAP. The feed to the anaerobic reactor was a mixture of the preclarified wastewater and return sludge. The next two reactors served as the intermittent aeration tank. The capacity of the anaerobic reactor and each of the two intermittent aerobic reactors was $4 \mathrm{~L}$ and $9.8 \mathrm{~L}$, respectively. The tanks were acrylic rectangular-type. The air was automatically controlled through the connection of an air pump and solenoid valve to a timer. The paddle was rotated at a speed of $120 \mathrm{rpm}$ to mix the influent wastewater with the sludge in the reactor for the anaerobic stage. The dissolved oxygen (DO) was maintained at 3.0 to $4.0 \mathrm{mg} / \mathrm{L}$ during the aeration. Aeration and non-aeration periods were alternated at intervals of $1.0 \mathrm{hr}$. That is, when the first reactor is aerated, the second reactor is not aerated or vice versa.

\subsection{Dynamic-Flow Intermittent Aeration Activated Sludge Process}

The DFP consisted of one anaerobic reactor and three intermittently aerated reactors as shown in Fig. 2. This is a new tank

Table 1. Characteristics of domestic wastewater

\begin{tabular}{lccccccc}
\hline Parameter & $\mathrm{pH}$ & TCODcr & SCODcr & $\mathrm{TKN}$ & $\mathrm{NH}_{4}^{+}-\mathrm{N}$ & $\mathrm{T}-\mathrm{P}$ & Ortho-P \\
\hline Max.-Min. & $6.5-7.5$ & $105-540$ & $47-205$ & $22-49$ & $14-34$ & $2.5-17$ & $1.7-7.2$ \\
Avg. & 7.2 & 235 & 95 & 32 & 26 & 5.4 & 2.7 \\
\hline
\end{tabular}

Values are presented as number (mg/L).

TCOD : Total Chemical Oxygen Demand

SCOD : Soluble Chemical Oxygen Demand

TKN : Total Kieldahl Nitrogen

T-P : Total Phosphorous

Ortho-P: Ortho Phosphorus

Avg.: Average
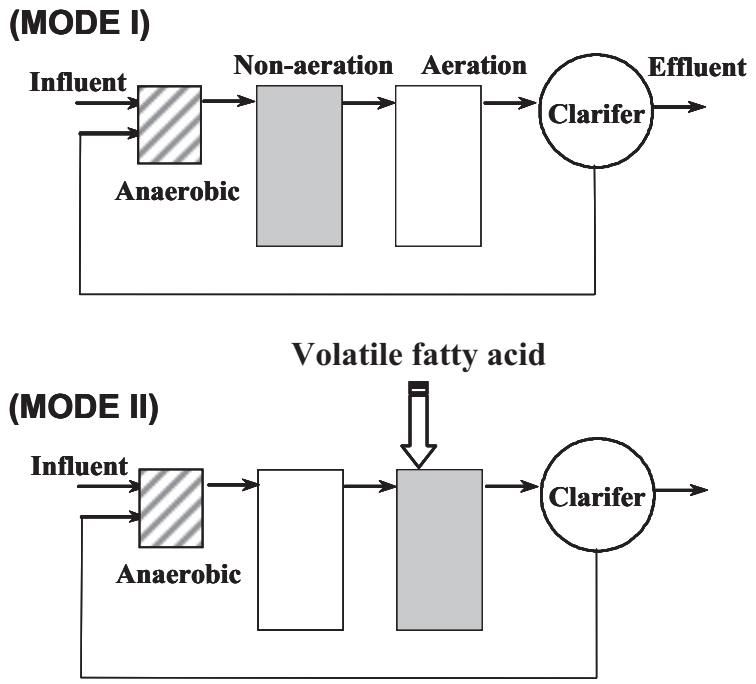

Fig. 1. Schematic diagram of the 2 stage intermittent aeration activated sludge process (IAP) for treating domestic wastewater.
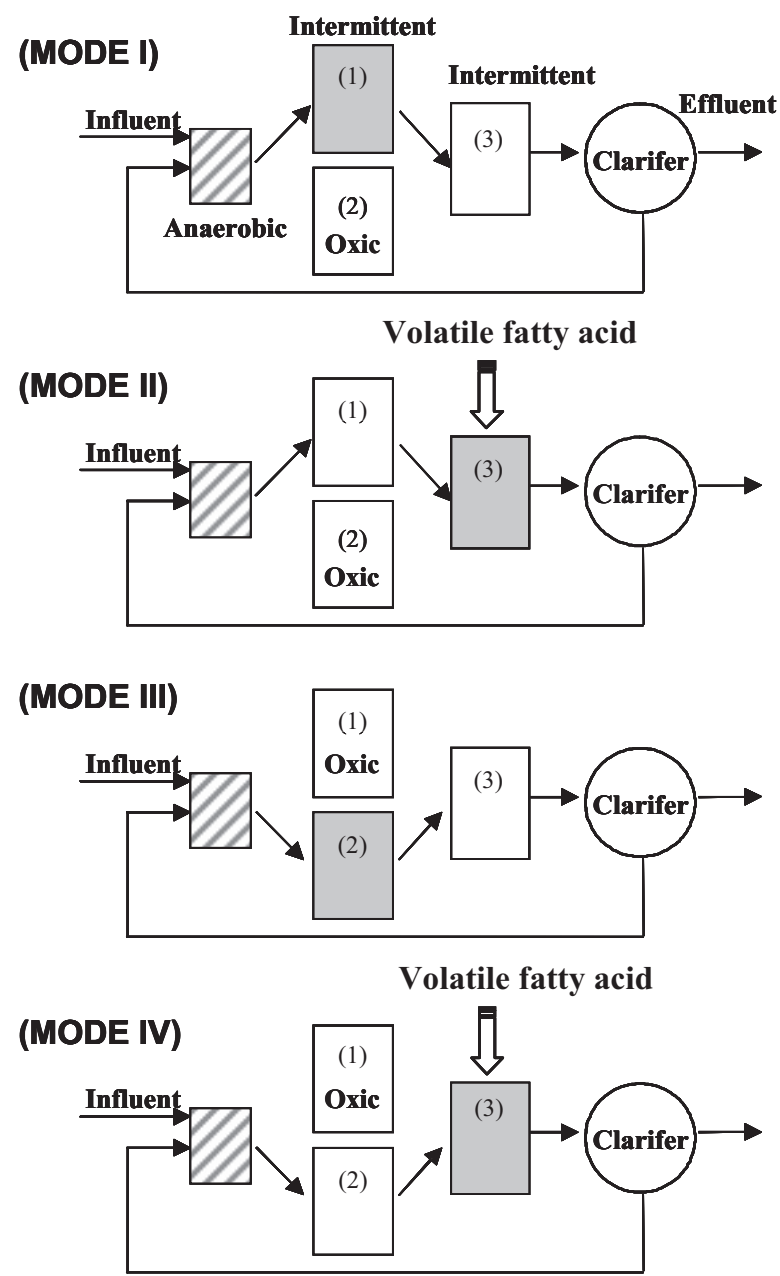

Fig. 2. Schematic diagram of the dynamic-flow intermittent aeration activated sludge process (DFP) for treating domestic wastewater. 
alteration process combined with an intermittent aeration system. Three tanks were used in which aeration alternates with anoxic conditions. The anaerobic and aerobic reactors of DFP were the same volume as that of IAP. The two reactors were operated by periodically changing the path of the flow through two parallel tanks that were aerated to a controlled strategy. Modes I, II, III, and IV in the system were operated to change the flow every $2 \mathrm{hr}$. The aeration and non-aeration times in reactors 1,2 , and 3 were set to $3 \mathrm{hr} / 1 \mathrm{hr}, 3 \mathrm{hr} / 1 \mathrm{hr}$, and $1 \mathrm{hr} / 1 \mathrm{hr}$, respectively. When the flow held, a batch reactor may be expected to maximize nitrification.

\subsection{Experimental Procedure}

The pilot plant of IAP and DFP was seeded with the return sludge of the domestic wastewater treatment plant located in Cheongju. The MLSS (Mixed Liquor Suspended Solid) concentration was maintained at $1,500 \mathrm{mg} / \mathrm{L}$ at the beginning of the operation and the changes of MLSS were observed. During the non-aeration period, VFA derived by the primary sludge hydrolysis was fed to the reactor immediately prior to the clarifier. The 1st set of IAP (0-IAP) as a control set was operated without VFA addition. The VFA was added to the 2nd set of IAP during the first $15 \mathrm{~min}$ of the non-aeration $60 \mathrm{~min}$ period (15-IAP), whereas the VFA was continuously added to the 3rd set of IAP (60-IAP) during the entire $60 \mathrm{~min}$ non-aeration period. The VFA was also continuously fed to the DFP reactor during the entire $60 \mathrm{~min}$ non-aeration operation. The ratio of VFA added as COD to the total nitrogen was 4.5 . The COD loading rate was maintained at $0.29 \mathrm{~kg} / \mathrm{m}^{3} /$ day. The sludge retention time (SRT), hydraulic retention time (HRT), and temperature were maintained relatively constant at 20 days, $12 \mathrm{hr}$, and $20 \pm 1^{\circ} \mathrm{C}$, respectively. The influent loading rate of the COD was $0.47 \mathrm{~kg} / \mathrm{m}^{3} /$ day on average. The influent, effluent, and activated sludge from each set were analyzed for COD, MLSS, MLVSS (Mixed Liquor Volatile Suspended Solids), TKN, $\mathrm{NH}_{4}-\mathrm{N}, \mathrm{NO}_{2}-\mathrm{N}$, and $\mathrm{NO}_{3}-\mathrm{N}$ by methods 5220 , $2540 \mathrm{D}, 2540 \mathrm{E}, 4500-\mathrm{N}_{\text {org }} \mathrm{B}, 4500-\mathrm{NH}_{3}, 4500-\mathrm{NO}_{2}{ }^{-}$, and $4500-\mathrm{NO}_{3}$ 2 , respectively, according to Standard methods [9], four to five times a week.

\section{Results and Discussion}

\subsection{Production of VFA from Primary Sludge}

All commonly used processes for biological nutrient removal (BNR) require a suitable carbon source in a sufficient quantity. The rates of denitrification depend on the type of carbon source [10]. In principle, the more easily degradable the carbon source, the higher the rates of denitrification that can be achieved. For enhanced biological phosphorus removal (EBPR) to occur, an anaerobic/aerobic sequence is required and fermentation products such as VFAs need to be present during the anaerobic phase in a sufficient amount. Not all carbon substrates can induce the occurrence of EBPR. The short-chain VFAs (acetic and propionic acid) are generally regarded as the best carbon sources for bio$\mathrm{P}$ removal. Most full-scale prefermenters are fed with primary sludge. The primary sludge hydrolysis and the production of VFA are experimentally quantified in Fig. 3 . The initial concentrations of VFA and SCOD in the settled sludge were $626 \mathrm{mg} / \mathrm{L}$ and $743 \mathrm{mg} / \mathrm{L}$, respectively. After 5 days of prefermentation, their concentrations increased to $1,570 \mathrm{mg} / \mathrm{L}$ and $2,400 \mathrm{mg} / \mathrm{L}$, which

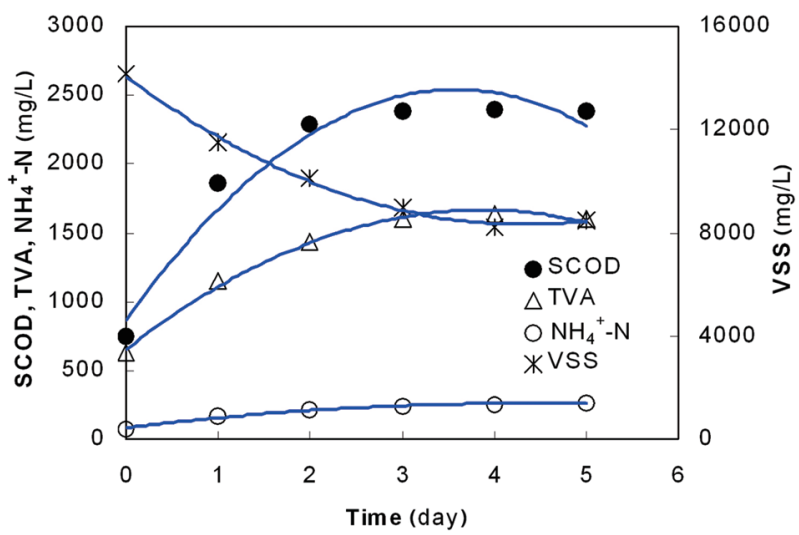

Fig. 3. Temporal variations of SCOD, TVA, $\mathrm{NH}_{4}{ }^{+} \mathrm{N}$, and VSS in fermented primary sludge.

SCOD : Soluble Chemical Oxygen Demand

TVA: Total Volatile Acid

VSS: Volatile Suspended Solids

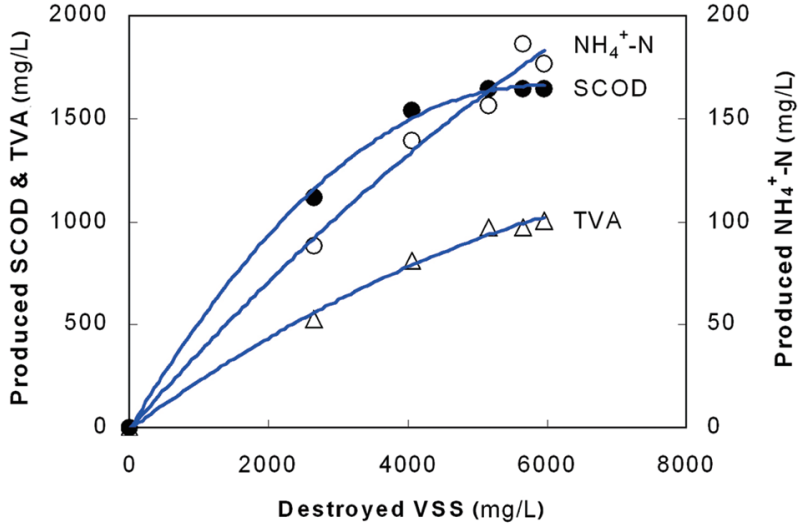

Fig. 4. Relationship between SCOD, TVA production and VSS decomposition.

SCOD : Soluble Chemical Oxygen Demand

TVA: Total Volatile Acid

VSS: Volatile Suspended Solids

correspond to 2.5 times and 3.2 times increase, respectively. Forty percent of VSS (Volatile Suspended Solids) was decomposed after 5 days prefermentation. In the prefermenters, a portion of the complex organic matter within the wastewater is converted into a form that is more suitable as a substrate for denitrifying and bio-P removing of bacteria, thus enhancing the nutrient removal performance of the plant. This value was also comparable with the values of $0.23 \mathrm{gVFA} / \mathrm{gVSS}$ at $35^{\circ} \mathrm{C}$ obtained from primary domestic sludge [8]. The maximum soluble organic production per sludge initial VSS in another study has ranged from 0.090 to $0.294 \mathrm{gSCOD} / \mathrm{gVSS}$, with the mean value of $0.161 \mathrm{gSCOD} / \mathrm{gVSS}$ at over $20^{\circ} \mathrm{C}$ [11].

Lee et al. [8] observed that VFA was produced at a relatively higher rate when the temperature was maintained at $35^{\circ} \mathrm{C}, \mathrm{pH}$ 7.0-7.2 adjustment, and $50 \mathrm{rpm}$ mixing in jar tester. However, VFA was produced in this study under the conditions of a temperature of $28^{\circ} \mathrm{C}$, no mixing and no $\mathrm{pH}$ adjustment for on-site application in the summer season. Ammonia nitrogen was slightly increased compared to the changes of SCOD and VFA. 


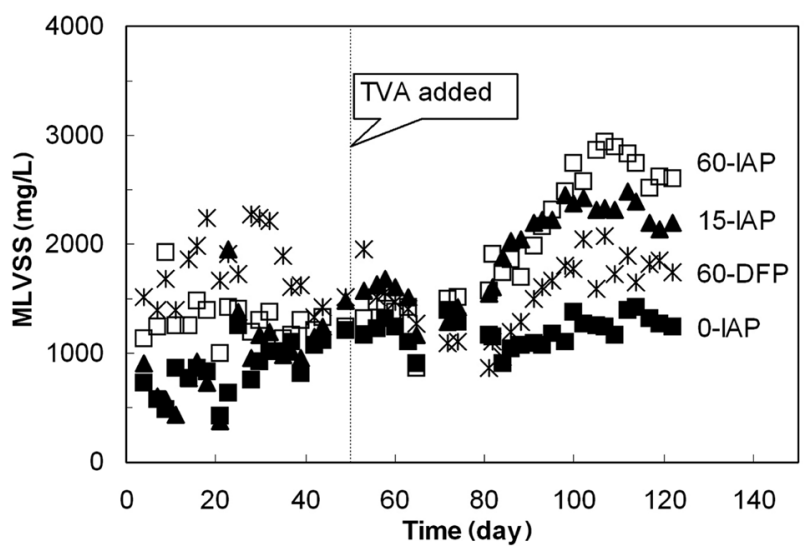

Fig. 5. MLVSS variations with 0-IAP, 15-IAP, 60-IAP, and 60-DFP IAP: no addition of VFA to IAP reactor 1, 15-IAP: VFA addition to IAP reactor 2 during the 1 st 15 min of non-aeration period, 60-IAP: VFA addition to reactor 3 all the $60 \mathrm{~min}$ of non-aeration period, 60-DFP: VFA addition to DFP reactor during all the 60 min non-aeration period. IAP: intermittent aeration activated sludge process, DFP: dynamic-flow intermittent aeration activated sludge process, VFA: volatile fatty acid.

MLVSS: Mixed Liquor Volatile Suspended Solids

TVA: Total Volatile Acid

Fig. 4 shows the correlations between the VSS decomposed and VFA produced. At $28^{\circ} \mathrm{C}$, the amount of VFA produced was $0.25 \mathrm{~g} /$ gVSS. This value was comparable with the values of $0.23 \mathrm{gVFA} /$ gVSS at $35^{\circ} \mathrm{C}$ obtained from primary domestic sludge [8]. Maximum soluble organic production per sludge initial VSS in another study has ranged from 0.090 to $0.294 \mathrm{gSCOD} / \mathrm{gVSS}$, with the mean value of $0.161 \mathrm{gSCOD} / \mathrm{gVSS}$ at over $20^{\circ} \mathrm{C}$ [11].

The production of $\mathrm{NH}_{4}-\mathrm{N}$ and VFA was linearly correlated ( $\mathrm{r}$ $=0.92$ ). $0.15 \mathrm{~g}$ of NH4-N was produced as $1 \mathrm{~g}$ of VFA was produced. Therefore, along with $\mathrm{NH}_{4}-\mathrm{N}$, the VFAs were furnished as the external electron donors. The amount of organic acids added was significantly higher than $\mathrm{NH}_{4}-\mathrm{N}$. This means that the $\mathrm{NH}_{4}^{-}$ $\mathrm{N}$ production during prefermentation may be negligible to the nutrient removal in IAP and DFP.

\subsection{Temporal Variations of MLVSS}

The variation of MLVSS during the 4 mon of operation is shown in Fig. 5. VFA was not added in the period of the first 50 days operation. The MLSS and MLVSS reached up to 2,000 and $1,500 \mathrm{mg} / \mathrm{L}$ after 40 days operation, respectively. In the two-stage IAP without the VFA addition as a control, MLSS and MLVSS were maintained relatively constant throughout the operation. When VFA addition was started, the concentration of MLVSS was gradually increased. As VFA was continuously fed during the 15 and $60 \mathrm{~min}$, the MLVSS concentrations in two-stage IAP were increased up to $2,500 \mathrm{mg} / \mathrm{L}$ and $3,000 \mathrm{mg} / \mathrm{L}$, respectively. In the DFP, the MLVSS concentration increased to $2,070 \mathrm{mg} / \mathrm{L}$. It is shown that a portion of the complex organic matter within the sludge is converted into a form that is more suitable as a carbon substrate for activated sludge. Also, the effect of VFA addition on the production of microbial biomass was more pronounced in the 60 min of feeding than in the 15 min of feeding for the twostage IAP. The ratio of MLVSS to MLSS was 0.8 on average, regardless of VFA feeding. A biochemical approach by Jung et al. [12]

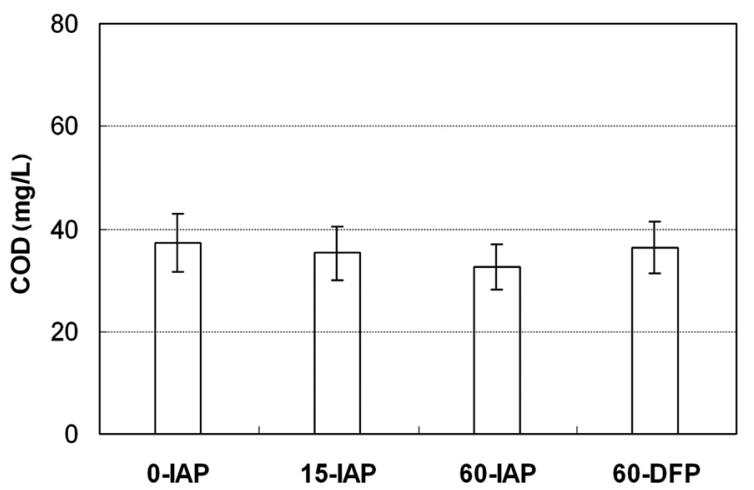

Fig. 6. Effluent COD concentrations with 0-IAP, 15-IAP, 60-IAP, and 60-DFP. IAP: intermittent aeration activated sludge process, DFP: dynamic-flow intermittent aeration activated sludge process. COD : Chemical Oxygen Demand

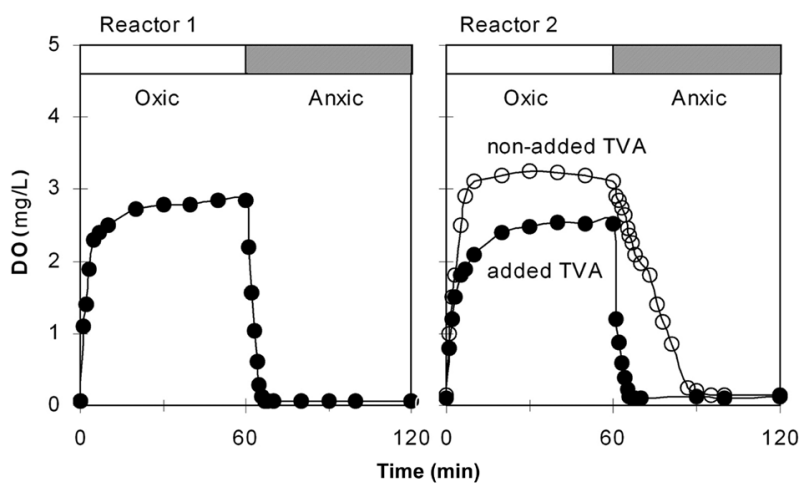

Fig. 7. DO profile in two-stage intermittently aerated activated sludge system. TVA: total volatile acid.

DO : Dissolved Oxygen

TVA: Total Volatile Acid

showed sludge reduction by repeatedly changing the microbial environment from an aerobic to an anaerobic condition in the intermittent aeration system.

\subsection{COD Removal and DO Changes}

The effect of VFA feeding on the microbial growth was also observed from the measurement of effluent COD. The effluent COD was 20 to $55 \mathrm{mg} / \mathrm{L}$, which was independent of the VFA feeding, even though the influent COD fluctuated resulting from the use of the in situ wastewater during the operation of the system (Fig. 6). This may be because VFA derived from the primary settling sludge can be easily degradable by microorganisms. Therefore, it appears that the effluent COD may not be affected by VFA feeding itself. Temporal variation of DO concentration in the two-stage IAP is shown in Fig. 7. In reactor 1, the DO concentration was decreased to $0.2 \mathrm{mg} / \mathrm{L}$ after $7 \mathrm{~min}$ of non-aeration, which indicated that the aerobic condition was changed to an anoxic condition as a result of influent organics degradation. In reactor 2 , it took $35 \mathrm{~min}$ and $7 \mathrm{~min}$ to make the anoxic condition without and with VFA feeding, respectively. In other words, time is required in the reactor to make the anoxic condition in 
which there is a lack of organic substrate in the period of nonaeration. The results suggest that the DO could not be consumed easily without a carbon source. Some researchers reported that the anoxic condition was rapidly formed under the conditions of rich organics and high MLVSS in the transition state from the aeration to the non-aeration condition. However, the addition of VFA and the adjustment of the aeration and non-aeration time should be accomplished in the domestic wastewater of low organics. Therefore, if the DO concentration in the aeration tank is sufficiently maintained at the level of 1.5 to $2 \mathrm{mg} / \mathrm{L}$ to perform nitrification, it is likely that the oxygen consumption of organic materials will decrease and the denitrification rate will be enhanced.

\subsection{Nitrogen and Phosphorous Removal}

The TKN loading rate was $0.064 \mathrm{~kg} \mathrm{~N} / \mathrm{m}^{3} /$ day in both twostage the IAP and the DFP designed for domestic wastewater treatment. Temporal variations of the nitrogen concentration in the influent and effluent are shown in Fig. 8. Concentrations of TKN and $\mathrm{NH}_{4}-\mathrm{N}$ in the influent and effluent were $32,26,4$, and $2 \mathrm{mg} / \mathrm{L}$, respectively. Since toxic compounds were not present in the influent, it is likely that nitrification was satisfactory.

The $\mathrm{NO}_{3}-\mathrm{N}$ concentration was 16 to $20 \mathrm{mg} / \mathrm{L}$ before VFA feeding. As VFA was added after 50 days operation, the $\mathrm{NO}_{3}-\mathrm{N}$ concentrations in the systems of 15-IAP, 60-IAP and 60-DFP were decreased. The $\mathrm{NO}_{3}-\mathrm{N}$ concentration was $5 \mathrm{mg} / \mathrm{L}$ in 15 -IAP and 1 to $3 \mathrm{mg} / \mathrm{L}$ in 60-IAP and 60-DFP, whereas the $\mathrm{NO}_{3}-\mathrm{N}$ concentration in the control system without VFA addition was maintained at about $15 \mathrm{mg} / \mathrm{L}$. This indicated that denitrification was not sufficient due to the low carbon source available to microorganisms without VFA addition. Nitrite was not accumulated in all the systems operated. Removal efficiencies for nitrogen with 15-IAP and 60 -IAP were $72 \%$ and $76 \%$, and for phosphorous were $65 \%$ and $81 \%$, respectively. Large differences of phosphorous were observed between 15-IAP and 60-IAP. The continuous VFA addition for 60 min resulted in better performance for both nitrogen and phosphorous removal compared to the first 15 min VFA addition during the non-aeration period. Denitrification mainly occurs under low oxygen concentration in the early stage of IAP operation. Fig. 9 shows that the best results were obtained with 60-DFP.

Issacs et al. [5] concluded that the denitrification rate in an alternating activated sludge process has been shown to be limited by the availability of readily degradable COD. The limited carbon source may affect phosphorous removal more than nitrogen removal. This could be explained by a possible competition between phosphorous removal bacteria and denitrifying bacteria. The easily degradable short chain organic acids required for the phosphorous removing bacteria would be consumed mostly by denitrifying bacteria. As a consequence, organic acids available for phosphorous removing bacteria are limited. Iwema and Meunier [13] attempted to confirm experimentally the above hypothesis and concluded that phosphorous removing bacteria efficiently compete with denitrifying bacteria for acetic acid in a batch experiment. Removal efficiency for total nitrogen in a 1.0 hr interval intermittent aeration process was $96.9 \%$, and for total phosphorous was $80.8 \%$ by Osada et al. [3]. Phosphorous removal with 4 different process sets showed the same tendency as nitrogen removal. That is, high removal efficiencies were achieved with continuous feeding of VFA in the period of non-aeration. If an anaerobic phase is introduced in the anaerobic-aerobic

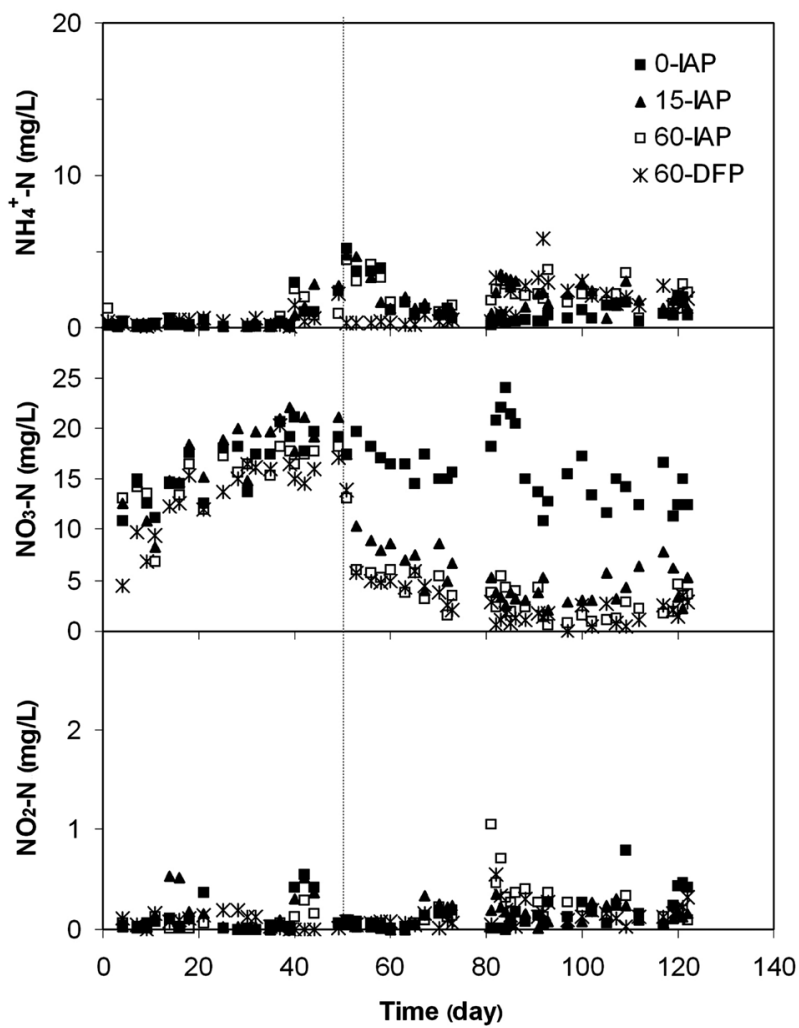

Fig. 8. Nitrogen variations during operations of 0-IAP, 15-IAP, 60IAP, and 60-DFP. IAP: intermittent aeration activated sludge process, DFP: dynamic-flow intermittent aeration activated sludge process.

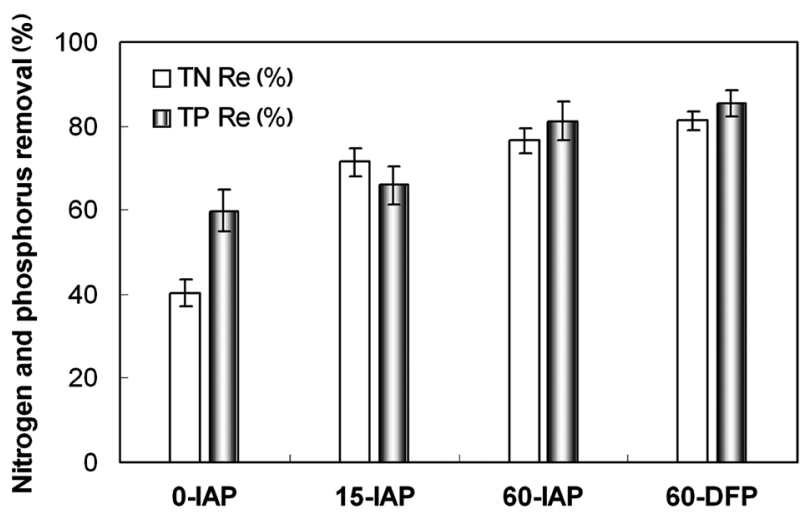

Fig. 9. Removal efficiencies of nitrogen and phosphorus removal with intermittent aeration activated sludge process. IAP: intermittent aeration activated sludge process, DFP: dynamic-flow intermittent aeration activated sludge process.

TN Re: Total Nitrogen Removal Efficiencies TP Re: Total Phosphorous Removal Efficiencies

configuration, microorganisms capable of anaerobically taking up carbon sources are favored. PAOs (Phosphate accumulating Organisms)can perform this because they are able to hydrolyze stores of poly-P in order to supply energy for the anaerobic uptake of the carbon sources [14]. Comeau [15] and Wentzel et al. [16] reported that $\mathrm{P}$ was effectively released in the presence of short chain volatile fatty acids (SCVFA) and in the anaerobic 
condition. Our experimental results showed that the fermented organic acids obtained from the primary settling sludge in domestic wastewater could be used as an external C source for the removal of nitrogen and phosphorus in wastewater having a low $\mathrm{C} / \mathrm{N}$ ratio and for the effective management of solid wastes in terms of economic aspects.

\section{Conclusions}

The fermented organic acids derived from the primary settling sludge of the domestic wastewater were evaluated in this study for the potential capability of utilizing them as the external carbon source in the denitrification. The two-stage IAP and DFP were operated. The conclusions were as follows.

1) The yield of VFA from primary domestic sludge was $0.25 \mathrm{~g} /$ gVSS at $28^{\circ} \mathrm{C}$ within 5 days.

2) Removal efficiencies for nitrogen with 15-IAP (addition of VFA during the first $15 \mathrm{~min}$ of the anoxic $60 \mathrm{~min}$ period) and 60 IAP (addition of VFA during the entire $60 \mathrm{~min}$ anoxic operation) were $72 \%$ and $76 \%$, and for phosphorus were $65 \%$ and $81 \%$, respectively. Nitrogen and phosphorous removal efficiencies with 60-DFP (addition of VFA during the entire 60 min anoxic operation mode to the dynamic-flow intermittent aeration process) were $81 \%$ and $80 \%$, respectively, which were about 2 times higher than those without VFA addition.

3) When hydrolyzed primary domestic sludge is employed as a source of readily metabolized carbon, PAOs seem to have an ability to compete with denitrifying bacteria.

\section{Acknowledgments}

The authors acknowledge the support by a study grant from Kyungnam University (2011).

\section{References}

1. Henze M. Capabilities of biological nitrogen removal processes from wastewater. Water Sci. Technol. 1991;23:669-679.

2. Zhao H, Isaacs SH, Søeberg H, Kümmel M. A novel control strategy for improved nitrogen removal in an alternating activated sludge process - Part II. Control development. Water Res. 1994;28:535-542.
3. Osada T, Haga K, Harada Y. Removal of nitrogen and phosphorus from swine wastewater by the activated sludge units with the intermittent aeration process. Water Res. 1991;25:1377-1388.

4. Sasaki K, Yamamoto Y, Tsumura K, Ouchit S, Mori Y. Development of 2-reactor intermittent-aeration activated sludge process for simultaneous removal of nitrogen and phosphorus. Water Sci. Technol. 1996;34:111-118.

5. Isaacs SH, Henze M, Søeberg H, Kümmel M. External carbon source addition as a means to control an activated sludge nutrient removal process. Water Res. 1994;28:511-520.

6. Hammer MJ. Water and wastewater technology. 4th ed. Upper Saddle River: Prentice Hall; 2001. p. 495.

7. Van Munch E, Greenfield PF . Estimating VFA concentrations in prefermenters by measuring pH. Water Research. 1988; 32:2431-2441

8. Lee SI, Koopman B, Park SK, Cadee K. Effect of fermented wastes on denitrification in activated sludge. Water Environ. Res. 1995;67:1119-1122.

9. Eaton AD, Clesceri LS, Greenberg AE, et al. Standard methods for the examination of water and wastewater. 19th ed. Washington, DC: American Public Health Association; 1995.

10. Tchobanoglous G, Burton FL, Metcalf \& Eddy. Wastewater engineering: treatment, disposal, and reuse. 3rd ed. New York: McGraw-Hill; 1991.

11. Hatziconstantinou GJ, Yannakopoulos P, Andreadakis A. Primary sludge hydrolysis for biological nutrient removal. Water Sci. Technol. 1996;34:417-423.

12. Jung SJ, Miyanaga K, Tanji Y, Unno H. Effect of intermittent aeration on the decrease of biological sludge amount. Biochem. Eng. J. 2006;27:246-251.

13. Iwema A, Meunier A. Influence of nitrate on acetic acid induced biological phosphate removal. Water Sci. Technol. 1985;17:289-294.

14. Mino T, Van Loosdrecht MC, Heijnen JJ. Microbiology and biochemistry of the enhanced biological phosphate removal process. Water Res. 1998;32:3193-3207.

15. Comeau Y. The role of carbon strage in biological phosphate removal from wastewater [dissertation]. Vancouver: University of British Columbia; 1989.

16. Wentzel MC, Lotter LH, Loewenthal RE, Marais Gv R. Metabolic behaviour of Acinetobacter spp. in enhanced biological phosphorus removal - a biochemical model. Water $S A$ 1986;12:209-224. 